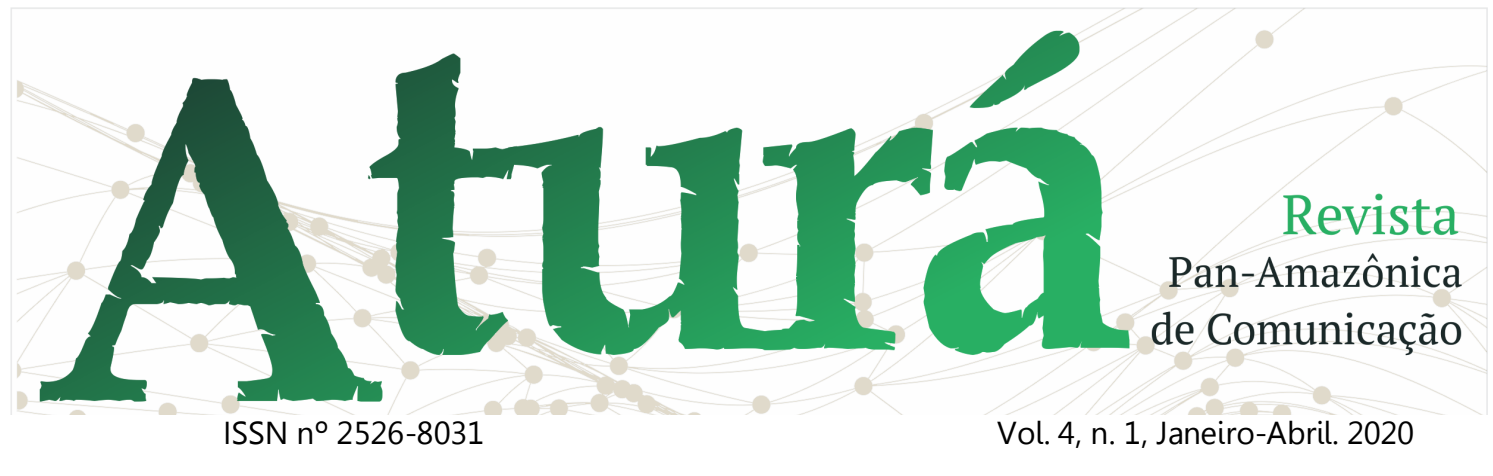

DOI: http://dx.doi.org/10.20873/uft.2526-8031.2020v4n1p17

\title{
FESTAS POPULARES AMAZÔNICAS: traços de colonialidade nas tramas da pós-modernidade
}

AMAZON POPULAR FESTIVALS:

coloniality traits in postmodern weft

FIESTAS POPULARES DE AMAZÓNICAS:

rasgos de colonialidad en una trama posmodernidad

\author{
Nair Santos Lima ${ }^{1}$ \\ Otacílio Amaral Filho ${ }^{2,3}$
}

\section{RESUMO}

As festas populares amazônicas remontam os tempos do subjugo colonial na região, mas que ainda hoje se mantém, embora ressignificada. Concebem-se as festas como constituídas das relações sociais da comunidade, as quais Simmel (1983) denomina de sociabilidades. Este ensaio pretende identificar traços de colonialidade nos cantos-enredos das "tribos" Muirapinima e Munduruku, de Juruti e dos Bois Garantido e Caprichoso, de Parintins, no ano de 2019. De abordagem qualitativa e de objetivo exploratório, a pesquisa tem por base o audiovisual, portanto, de delineamento documental. Propõe-se, portanto, um olhar descolonial, a partir da experiência da colonialidade, observadas no cotidiano dessas populações nas festas na pós-modernidade.

PALAVRAS-CHAVE: Festas populares amazônicas; Colonialidade; Sociabilidade; Pós-modernidade.

\footnotetext{
${ }^{1}$ Doutoranda do Programa de Pós-Graduação Comunicação, Cultura e Amazônia - PPGCOM/UFPA. Mestra em Ciências da Comunicação pela Universidade Federal do Amazonas - UFAM. E-mail: nslima1405@gmail.com.

${ }^{2}$ Doutor em Ciências: Desenvolvimento Sustentável do Trópico Úmido (PPGDSTU) pelo Núcleo de Altos Estudos Amazônicos da Universidade Federal do Pará (NAEA/UFPA). Docente do Programa de Pós-Graduação Comunicação, Cultura e Amazônia - PPGCOM/UFPA. E-mail: otacilioamaralfilho@gmail.com.

${ }^{3}$ Endereço de contato com os autores (por correio): Universidade Federal do Pará, Instituto de Letras e Comunicação. Programa de Pós-Graduação em Comunicação, Cultura e Amazônia. Av. Augusto Correa, 01, Guamá. CEP: 66075-110. Belém, PA - Brasil.
} 


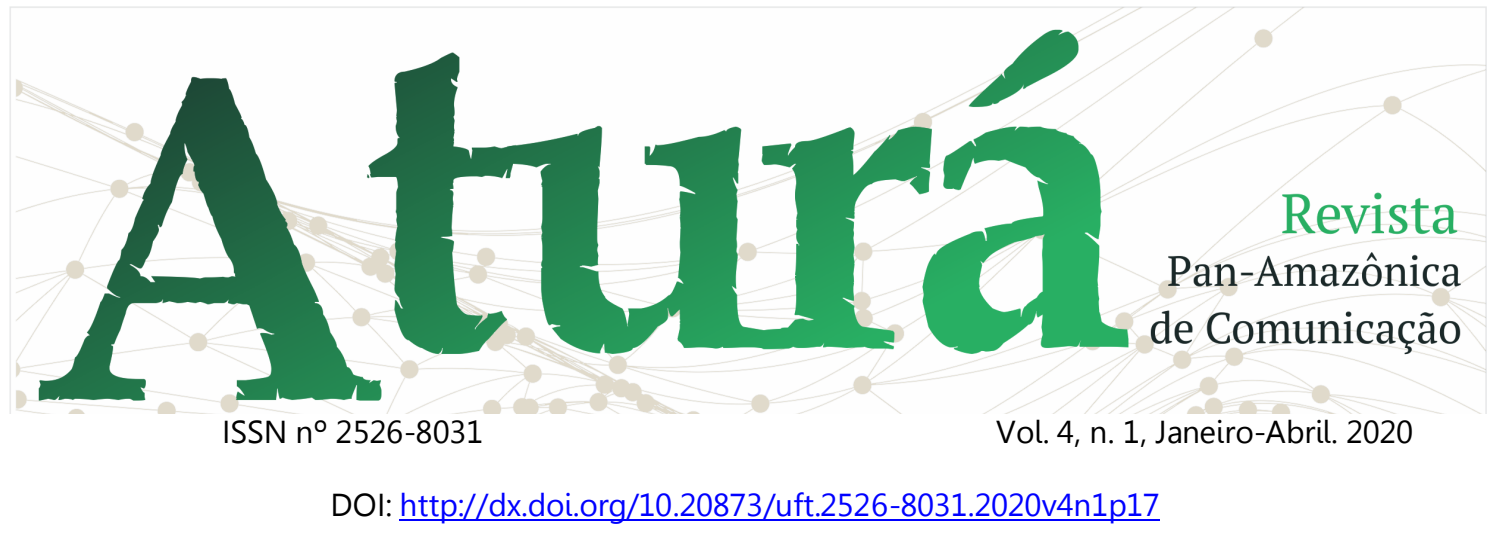

\begin{abstract}
The Amazonian popular festivals date back to the times of colonial subjugation in the region, but still today they remain resignified. The festivals are conceived as constituted of the social relations of the community, which Simmel (1983) calls sociability. This essay aims to identify traces of coloniality in the plot-corners of the Muirapinima and Munduruku "tribes" of Juruti and Parintins' Bois Garantido and Caprichoso in 2019. Based on a qualitative and exploratory approach, the research is based on audiovisual, therefore, of documentary delineation. For that reason, we propose a decolonial look, based on the experience of coloniality, observed in the daily life of these populations in the feasts in postmodernity.
\end{abstract}

KEYWORDS: Amazon popular festivals; Coloniality; Sociability; Postmodernity.

\title{
RESUMEN
}

Las fiestas populares amazónicas se remontan a los tiempos de la subyugación colonial en la región, pero aún hoy, aunque re-significados. Los partidos Las partes se conciben como constituidas por relaciones sociales de la comunidad, lo que Simmel (1983) llama sociabilidad. El objetivo de este ensayo es identificar las huellas de la colonialidad en las líneas argumentales de/ las "tribus" Muirapinima y Munduruku de Juris y Bois Garantido y Caprichoso de Parintins en 2019. Basado en un enfoque cualitativo y exploratorio, la investigación se basa en la delineación audiovisual y por lo tanto documental. Por lo tanto, se propone una mirada descolonial, basada en la experiencia de la colonialidad, observada en la vida cotidiana de estas poblaciones en las fiestas en la posmodernidad.

PALABRAS CLAVE: Fiestas populares amazónicas; Colonialidad; Sociabilidad; Posmodernidad.

Recebido em: 12.11.2019. Aceito em: 12.12.2019. Publicado em: 03.01.2020. 


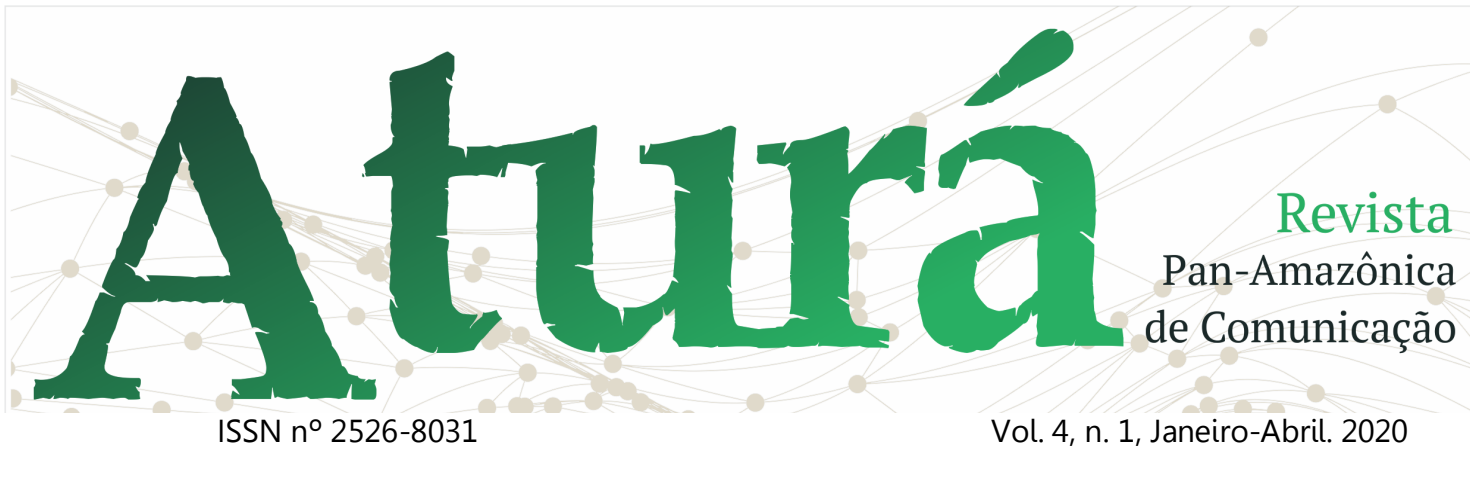

DOI: http://dx.doi.org/10.20873/uft.2526-8031.2020v4n1p17

\section{A Amazônia e suas festas}

A Amazônia não foi descoberta, sequer foi construída; na realidade, a invenção da Amazônia se dá a partir da construção da Índia, fabricada pela historiografia grecoromana, pelo relato dos peregrinos, missionários, viajantes e comerciantes (GONDIM, 1994, p. 09)

Antes mesmo da chegada dos viajantes europeus, a região era habitada por uma sociedade complexa ${ }^{4}$ - de grande atividade econômica e cultural - originária dos primeiros grupos nômades que atravessaram a floresta por volta de $\mathbf{1 5 . 0 0 0}$ anos atrás dando origem colonização da Amazônia. Por volta de 8000 e 4000 a. C., grupos de caçadores e coletores constituíram uma comunidade de alta sofisticação ${ }^{5}$. Mais tarde, em um período de 4000 a 2000 a. C., esses povos compunham uma sociedade de subsistência, ou seja, viviam da pesca, da caça e da agricultura, além da habilidade

\footnotetext{
${ }^{4}$ Nas últimas décadas, uma série de estudos tem contrastado com as posições que se estabeleceram sobre a ocupação do solo amazônico. Por meio de novas pesquisas, como a da arqueóloga Anna Roosevelt (sobre as culturas da ilha de Marajó e da calha amazônica), constata-se que a Amazônia contemplava em tempo
}

no cultivo de plantas e na criação de animais.

A existência de artefatos encontrados pertencentes a outros povos prova o comércio e o transporte que eles realizavam em longas viagens. Daí, inferese a presença de povos coletores nos muitos sambaquis encontrados próximo à foz do rio Amazonas, na costa do Suriname e em algumas áreas do baixo Amazonas, por volta de 3000 a. C. Nesses depósitos, as camadas mais recentes compunham-se de restos de cerâmicas decoradas com figuras de animais.

Em "Tesouro descoberto no máximo rio Amazonas", Daniel (2004) relata que os índios eram muito amigos de festas, danças e bailes e, nesses eventos, entregavam-se a memoráveis "beberronias" e que a música aliava-se a um intuito utilitário. Servia tanto para o trabalho quanto para a recreação, festas e

pré-histórico um cenário rico e de diversas sociedades humanas.

${ }^{5} \mathrm{~A}$ utilização de ferramentas para cavar petróglifos nas cavernas e "Outros artefatos de pedra encontrados nos altiplanos venezuelanos e na Guiana, bem como nas barrancas do rio Tapajós" (SOUZA, 2001, p. 20). 


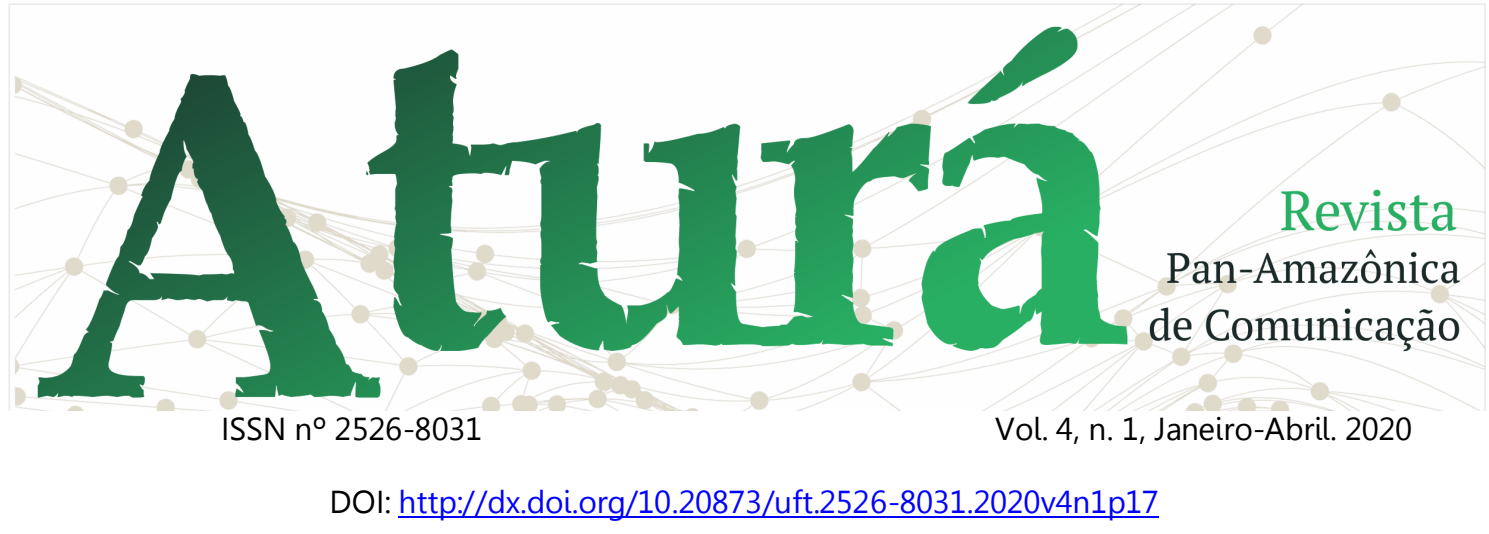

folguedos. Havia cânticos para ocasiões especiais: guerreiros, núpcias, fúnebres e até mesmo báquico e erótico, assim como danças específicas para cada atividade. A música era utilizada para influenciar os índios, que se aproximavam dos conventos seduzidos, segundo Daniel (2004), por meio do tom alegre dos sinos, dos cânticos da missa, das danças e da própria cerimônia religiosa. Antes, essas atividades eram compartilhadas apenas como um ato comum de movimento social.

Nos estudo sobre a festa, objeto das reflexões e comentários de Émile Durkheim na obra "Les formes elementaire le vie religieuse" (1912) ${ }^{6}$, o autor trata da relação entre ritual e festas e aponta para os limites "flutuantes" entre os ritos representativos e as recreações coletivas. Para o autor, o elemento recreativo e estético é a característica presente em toda religião. Além disso, "toda festa, mesmo quando puramente laica em suas origens, tem certas características de cerimônia religiosa" (DURKHEIM, 1968 apud AMARAL, 1998, p. 1).

As festas aqui tratadas referem-se às manifestações culturais que, de modo particular em cada região brasileira celebra seus costumes, tradições, modos de vida etc., ressaltando que, desde o período colonial esses modos de festejar se faziam presentes entre as tribos e,

(...) longe de ser um fenômeno de distanciamento da realidade, fuga psicológica etc., cujo resultado seria negar ou reiterar ao modo pelo qual a sociedade se encontra organizada, nossas festas são capazes de estabelecer a mediação entre a utopia e a ação transformadora, pois através da vontade de realização da festa muitos grupos se organizam, em nível local, chegando até mesmo a crescer política e economicamente, mesmo que em modo local" (AMARAL, 1998, p.11).

No contexto amazônico em que essas festas se inserem, encontra-se uma diversidade de modos e fundamentos diferentes que culminam com a realização de muitos eventos, como o Festival de Parintins, a Ciranda de Manacapuru (ambos no Amazonas), o Sairé e o Festival das Tribos, (ambos no Pará), além de

\footnotetext{
${ }^{6}$ Neste artigo é usada a versão de 1968.
} 


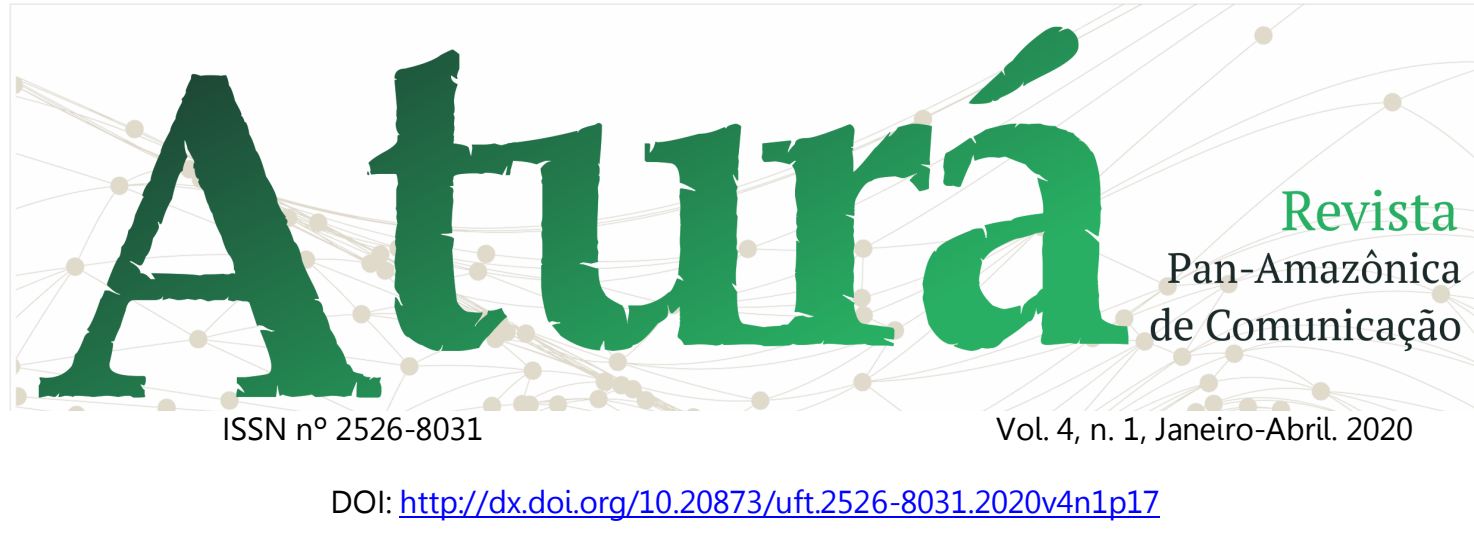

outras cujos objetivos primordiais são a promoção da lavoura. Como exemplo, pode-se considerar a Festa do Guaraná, em Maués, o Festival do Abacaxi, em Presidente Figueiredo (ambos no Amazonas), e, sobretudo, o Festival da Tapioca, em Boa Esperança, no município de Santarém (no Pará).

Pode-se considerar que a festa da farinha da tapioca $^{7}$ difere das demais referenciadas por vários objetivos, dentre eles por congregar as famílias gaúchas nessa comunidade que dista $43 \mathrm{~km}$ da sede do município, Santarém (Rodovia PA370). Outra característica é o aprimoramento da culinária, a partir da lavoura da macaxeira (aipim), cujo cardápio de doces e salgados compõe a bibliografia da festa, além do incentivo à implementação de técnicas agrícolas, cujo aprimoramento fortalece a cadeia produtiva e o vínculo social dos indivíduos na percepção solidária, tanto da

\footnotetext{
${ }^{7}$ Essa localidade foi fundada nos anos 1960 e concentra uma população de sulistas que cultivam, além da tapioca, o milho, a soja e o arroz. Cerca de $70 \%$ das famílias nessa localidade produzem a tapioca. Essa festa também é chamada de Festa da Integração gaúcha.
}

preservação da cultura gaúcha quanto no atendimento das necessidades básicas da comunidade.

Entretanto, em todas elas, a promoção da economia se dá na produção e inserção de seus produtos no mercado local e regional, e isso se deve a uma espécie de insight por essas comunidades. De outro modo, observa-se que mesmo as festas que alcançaram maior projeção midiática, quer seja pelo turismo direcionado (dimensão cultural) ou por um modo de ação comunitária, trazem entretecidas em seus enredos, alegorias e adereços - histórias de um passado de subjugo ou subsunção de colonialidade.

\section{Traços de colonialidade tecidos nas produções da cultura paraense.}

Uma breve análise histórica do período colonial no Brasil se faz necessária para que se compreenda os traços de colonialidade $^{8}$ deixados e (ainda 


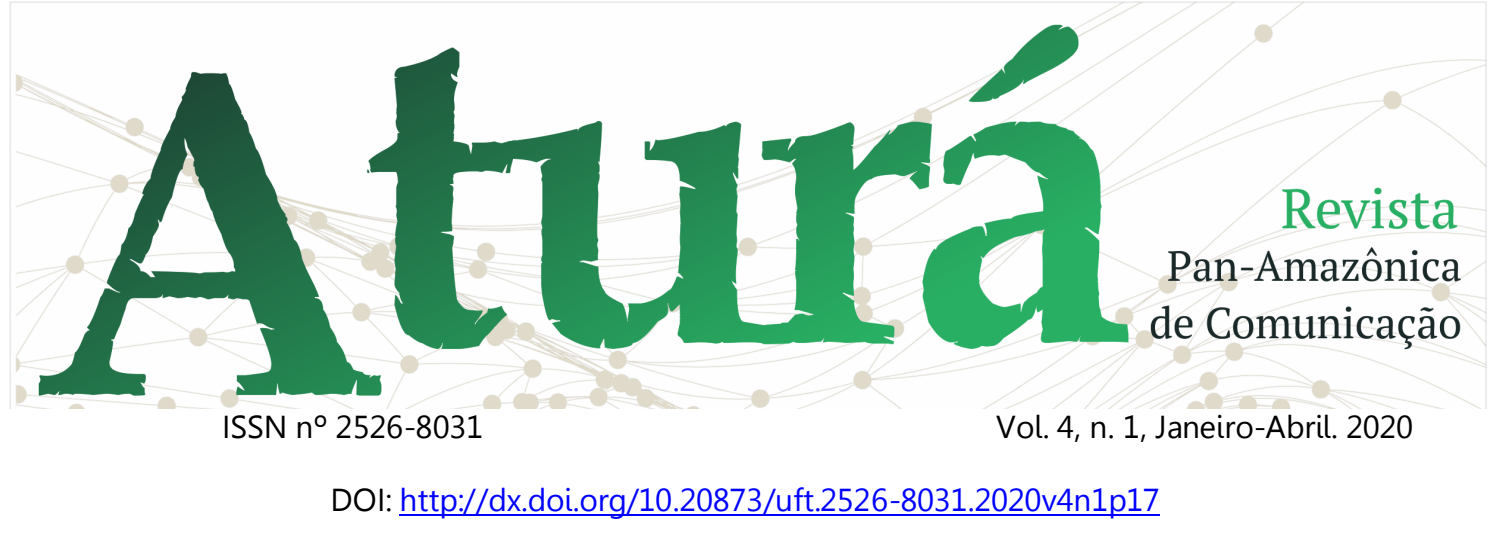

utilizados) transpassados pelas tramas das festas amazônicas. O termo colonialidade, cunhado por Quijano (1997), relaciona-se com "algo que transcende as particularidades do colonialismo histórico e que não desaparece com a independência ou descolonização" (ASSIS, 2014, p. 614). Desse modo, concebe-se a colonialidade instituída com a assinatura do Tratado de Tordesilhas, em 1494.

Com o objetivo inicial de exploração das terras conquistadas, três períodos se configuram na história da colonização do Brasil: o período Précolonial (1500-1549) caracterizado pela extração do pau-brasil; o Colonial (1549 final do século XVIII) com os ciclos do açúcar e do ouro e, o período denominado de Crise do Sistema Colonial (no final do século XVIII a 1822). Entretanto, foi no segundo período que houve maior lucratividade ${ }^{9}$ para os portugueses.

econômico-instrumentais de se pensar e explorar o meio ambiente (ASSIS, 2014, p. 613).

${ }^{9}$ No período colonial, com o crescimento da mão-deobra escrava (destinada ao ciclo do ouro e cana-de-

Com as reformas Pombalinas que ocorreram a partir de 1750 , sobretudo, a importância do mercantilismo diminuiu. Movimentos de rebeldia contra a administração surgiram e dentre eles, o da Inconfidência Mineira. Esse, portanto, configurou-se como o período de Crise do Sistema Colonial. Com efeito, nesse período, a Família Real chega ao Brasil (1808) alterando paulatinamente, mas de modo permanente a relação entre Metrópole e Colônia, resultando na Independência do Brasil, em 1822.

Ressalta-se, porém, que

(...) a extinção do colonialismo históricopolítico nas Américas, com a construção de nações independentes no século XIX, (...) não foi condição necessária e suficiente para a emancipação político-econômica e cultural dos países periféricos" (ASSIS, 2014, p. 613).

Nesse sentido, para que se compreenda a ideia de colonialidade permeada nas produções da cultura, convém esclarecer que os traços de

açúcar) as fronteiras foram sendo alargada, alcançando o sertão brasileiro, a Amazônia e regiões ao sul da colônia, na exploração das especiarias (drogas do sertão e algodão). 


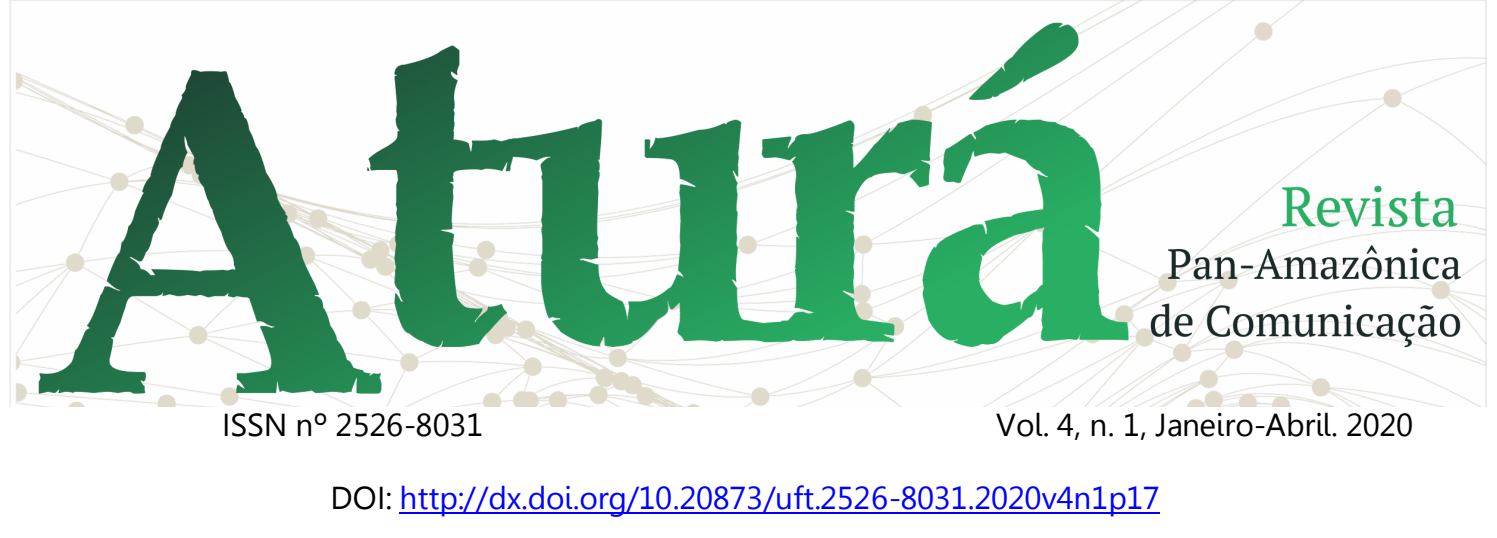

colonialidade, aqui proposto, está contemplado no próprio conceito que, de forma transversal, emerge em diferentes campos de conhecimento, a fim de discutir tendências e aspectos culturais diversos que resultaram em processos de colonialismo ${ }^{10}$.

A Colonialidade pressupõe poder de dominação de uma cultura noutra; atua nos modos de agir dos indivíduos e grupos sociais, nos comportamentos, valores, conhecimentos e saberes. "Para mim, a pauta oculta (e o lado mais escuro) da modernidade era a colonialidade (...) A colonialidade, em outras palavras, é constitutiva da modernidade - não há modernidade sem colonialidade" (MIGNOLO, 2017, p. 1-2)

Sob outra perspectiva,

Colonialismo precede a colonialidade, a colonialidade sobrevive ao colonialismo. A mesma permanece viva nos manuais de aprendizagem, no critério do bem acadêmico, na cultura, no senso comum, na autoimagem dos povos, nas aspirações dos sujeitos e em tantos outros aspectos de nossa experiência moderna. Em certo sentido, respiramos a colonialidade na

10 Nesse sentido, refere-se à dominação de ordem política e econômica de uma nação ou de um povo sobre

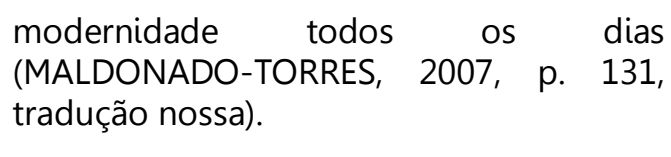

Em relação às produções culturais, Paes Loureiro (2001), em linguagem poética, reforça essa ideia ao afirmar que "nada está totalmente organizado em compêndios na cultura amazônica". E acrescenta: "É preciso errar pelos rios, tatear no escuro das noites da floresta, procurar os vestígios e os sinais perdidos pela várzea, vagar pelas ruas das cidades ribeirinhas" (LOUREIRO, 2001, p. 25).

Outros poetas, escritores e estudiosos da cultura registraram suas memórias em livros ou apenas nos jornais da época. Entretanto, outras informações não registradas ainda podem ser captadas por meio de investigação, a partir da perspectiva dos descendentes e associadas a outros tipos de documentos.

É o que sugere Leal (2017, p. 87) ao citar as produções de autores paraenses, tais como, Bruno de Menezes e Dalcídio Jurandir, nas quais as mães "são citadas

outro, numa relação (explícita) de poder, soberania e hegemonia. 


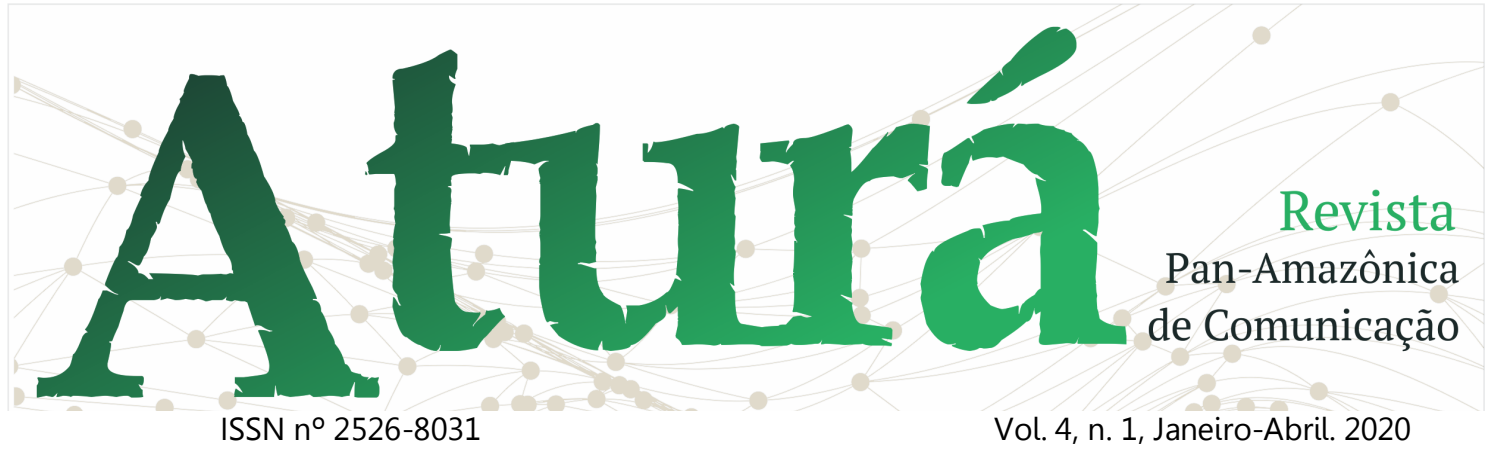

DOI: http://dx.doi.org/10.20873/uft.2526-8031.2020v4n1p17

como pessoas de grande importância para a inserção desses escritores no mundo da cultura negra paraense". Afirma Leal (2017, p. 87) que, "Todos os assuntos listados por Bruno, em sua dedicatória, estiveram relacionados com a sua vida e produção intelectual antes e após o movimento de 1938, pela liberdade de culto no Pará", ou seja, "O despertar do engajamento intelectual negro, em 1937, por ocasião das políticas de repressão aos terreiros afro religiosos, acarretou em debates e atitudes que integraram diferentes pensadores e artistas da Amazônia" (LEAL, 2017, p. 87, grifo nosso).

Em "Chove nos Campos de Cachoeira", Dalcídio Jurandir (1991, p. 78) assim descreve a mãe do personagem Alfredo: “D. Amélia era uma pretinha de Muaná, neta de escrava, dançadeira de coco".

Quando o major Alberto, já viúvo, se interessa por ela, apresenta-lhe o convite para que fosse morar com ele em seu chalé em Cachoeira. O convite era para que ela fosse cozinhar para ele. Quando souberam, suas filhas ficaram escandalizadas com a escolha do pai. A reação indignada expressava toda a violência do racismo presente naquela pequena vila marajoara contra a escolha de uma mulher negra para companheira de um homem branco de razoável prestígio (...). Em uma conversa entre dois personagens, Dejanira, uma senhora que vivia a fase da decadência de seus prestígios, lamenta os supostos privilégios de Amélia: 'Pensa que lá na casa de siá Amélia, pensa que aquela preta não come maçã? Pensa que ela não come uva? Come maçã, come uva. Quando chega semana santa come bacalhau! A preta. Bacalhau. Olha, que eu, uma criatura acostumada com todas essas coisas boas, sou obrigada a comer jiju! A comer este naco de carne velha e magra todo dia' (LEAL, 2017, p. 91).

Na história da música paraense, da primeira metade do século $X X$, a estreia da ópera "Bug Jargal" (melodrama de fins dos anos 1890) apresentou uma história ocorrida em 1790, em Santo Domingo colônia francesa antilhana - vivido por um escravo congolês (Jargal) que se apaixonou pela patroa branca (COSTA, 2016). A ópera que abria a temporada lírica em Belém e pioneira no regime republicano foi regida sob a batuta do paraense José Cândido da Gama Malcher (1853-1921).

O espetáculo, inserido no contexto da abolição da escravatura brasileira ressaltava um elemento inusitado: a dança do "autêntico carimbó" que foi 


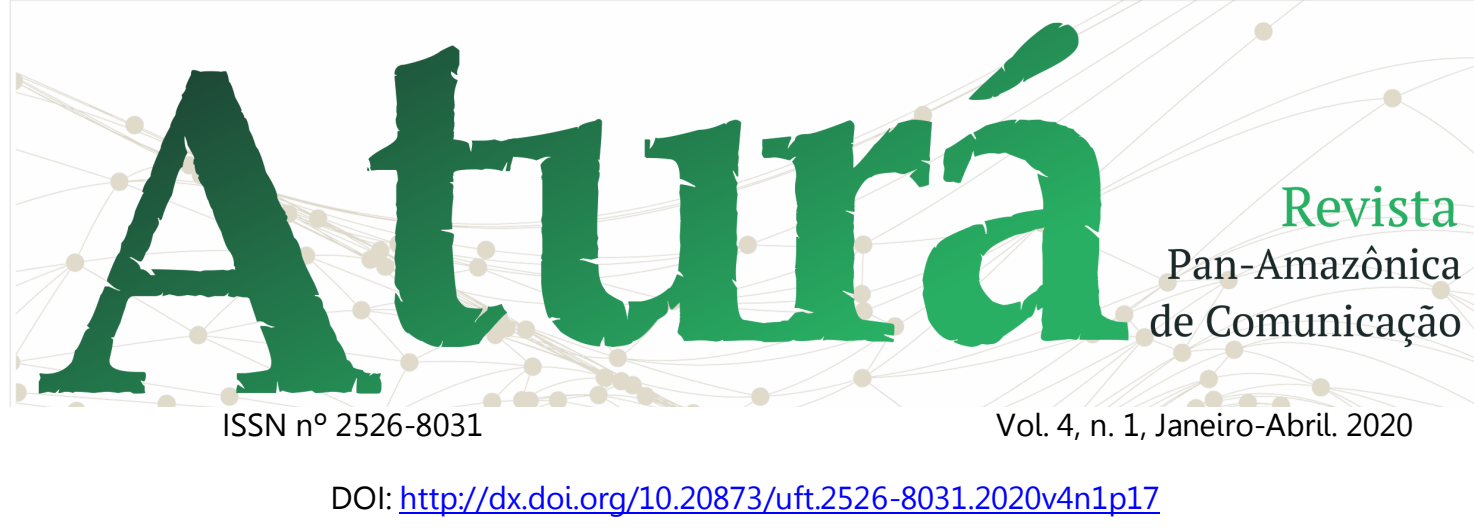

introduzido em lugar das danças do Caribe,

Com figurantes portando instrumentos típicos como o curimbó e o gambá. (...) os críticos locais da ópera, que publicaram suas resenhas em jornais locais na época, elogiaram $\mathrm{o}$ interesse do maestro por incluir "melodias de danças folclóricas da Amazônia" em sua obra. Mas alguns críticos tomaram essa iniciativa inusitada como atestado de selvageria dos músicos locais (SALLES, Vicente 2005b, p, 53 apud COSTA, 2016, p. 87).

Logo após a apresentação do musical, o escritor, jornalista e crítico de arte Antônio Marques de Carvalho, de " $A$ Província do Pará", publicou que "não teria tolerado a presença de tambores de carimbó na ópera, 'Imaginem os leitores um Espírito gentil, com aquele acompanhamento de carimbó!!! Mas qual! Somos nós que não passamos de selvagens, e não entendemos da coisa'" (SALLES, 2005b apud COSTA, 2016, p. 8788). De acordo com esta visão, "a 'selvageria' das músicas locais poderia se manifestar tanto com instrumentos percussivos como com violas e violões. Sobre estes últimos, por sinal, naqueles idos de 1890, ainda pairava a marca da 'vadiação dos negros'" (COSTA, 2016, p. 88).

Os traços de colonialidade tecidos culturalmente nas produções pós-colonial brasileira perduram e ainda persistem na atualidade, muito embora ressignificados ou assimilados como parte dos espetáculos culturais, especialmente, como produtos da indústria cultural. Em "No fundo das aparências", Maffesoli (2005) percebe que as ações que, na atualidade, integram a sociedade têm por base a futilidade, a aparência e a banalidade e que esses atributos dão razão e sentido à vida social cotidiana.

Ao dialogar, nessa obra, com o pensamento clássico de Durkheim, Maffesoli (2005) faz comparações com os aspectos da vida social pós-moderna e, sobretudo, voltados ao mundo da arte, literatura, música, escultura etc. Segundo o autor, as festividades não devem ser apercebidas como algo sem valor, isto por que os acontecimentos da cultura são produzidos por um conjunto de emoções coletivas reunidas em desejos que 


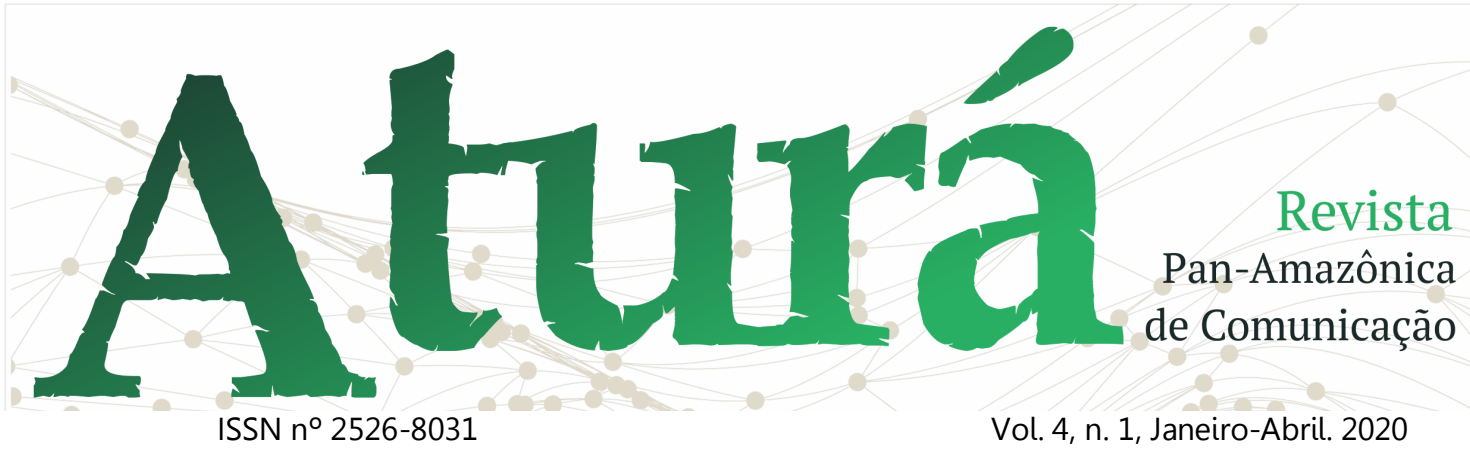

DOI: http://dx.doi.org/10.20873/uft.2526-8031.2020v4n1p17

exprimem alegria, satisfação, querência do viver, uma espécie de 'familiarismo' que caracterizam "muitas relações sociais contemporâneas" (MAFFESOLI, 1999, p. 96).

Embora esse olhar contemple as relações que se estabelecem-na complexidade da festa, ressalta-se que há questões mais profundas, subjetivas que permeiam esse ambiente e a consciência dos indivíduos. Diante disso,

O panorama que acabo de esboçar não é uma descrição do colonialismo, mas da colonialidade, da construção do mundo moderno no exercício da colonialidade do poder. Mas também das respostas da diferença colonial à coerção programada ou exercida pela colonialidade do poder. $O$ imaginário do mundo moderno/colonial surgiu da complexa articulação de forças, de vozes escutadas ou apagadas, de memórias compactas ou fraturadas, de histórias contadas de um só lado, que suprimiram outras memórias, e de histórias que se contaram e se contam levando-se em conta a duplicidade de consciência que a consciência colonial gera (MIGNOLO, 2005, p. 40).

Sugere 0 autor que se faz necessário descolonizar o pensamento, "para quem não tem uma verdadeira autoconsciência" e que "essa consciência tem de formar-se e definir-se em relação ao 'outro mundo'. Isto é, consciência vivida na diferença colonial é dupla porque é subalterna. A subalternidade colonial gera a diversidade de consciências duplas" (DU BOIS, 1904 apud MIGNOLO, 2005, p. 40)

\section{As festas e a sua inserção na pós- modernidade}

$\mathrm{Na}$ cultura brasileira, as festas refletem momentos de congraçamento de um conjunto de indivíduos ou comunidade, expressos em seus objetivos, finalidades ou, ainda, na tradição de cada povo. Evidenciam-se por seus múltiplos sentidos, como linguagem simbólica e ocorre de modo particular, dependendo do espaço geográfico e/ou regional. Há uma diversidade de festas e que a elas são referidas "festivais", "espetáculos", "festas indígenas", a saber: o festival dos Bois de Parintins e Cirandas de Manacapuru (Amazonas); Sairé; Tribos de Juruti; Círio de Nazaré; Arraial do Pavulagem e Marujada em Bragança (Pará) e Marabaixo (Macapá). 


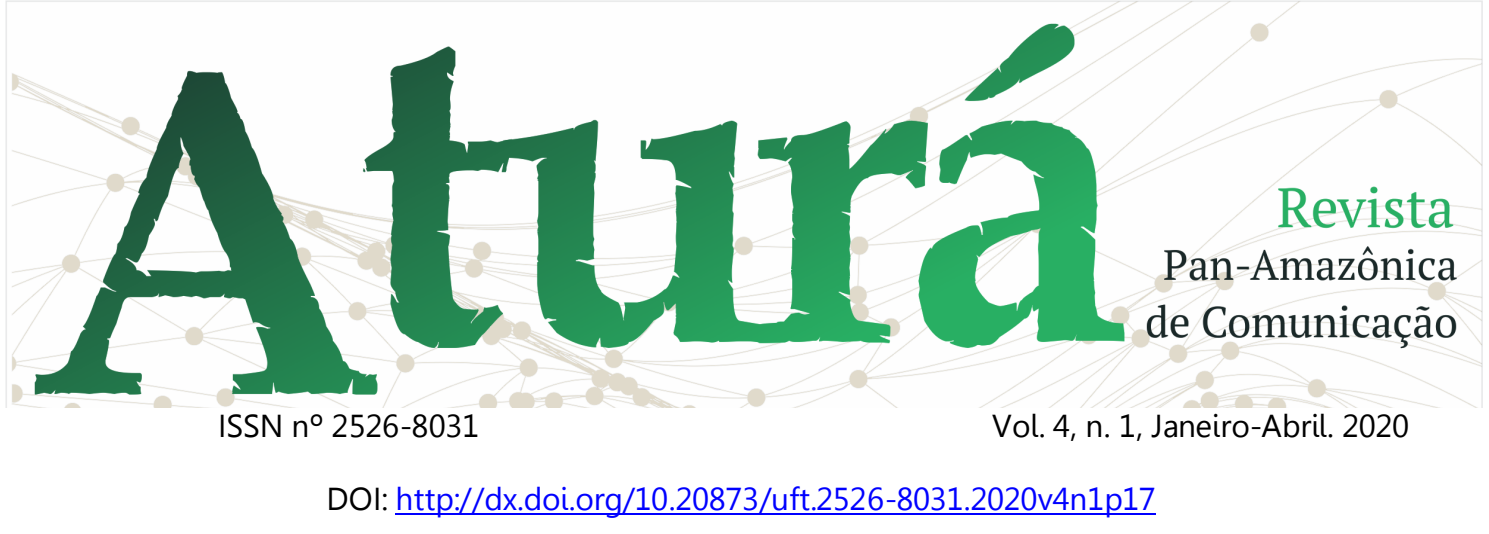

Entretanto, não se pode desconsiderar, também, o modus vivendi dessas populações próprias dessa região, visto que a relação desses indivíduos com a natureza se dá em um complexo ambiente de cultura povoado de mitos e símbolos, de emoção e de poesia. Essa é a realidade do homem amazônico, aquele que vive todas as possibilidades em seu próprio mundo, não somente, mas além do real, um mundo tão denso e vasto, dentro e fora da floresta, um mundo imaginário (LOUREIRO, 1985, p. 09-16), e que esse ambiente se constitui de um cenário subjetivo que se reatualiza a cada ano e simbolicamente, visto que a cada novo ano o círculo que se fechou recomeça. Portanto, de maneira global, a festa se elabora das interações entre as pessoas.

Para Amaral (1998, p. 7-8), as festas decorrem de

Um fator constitutivo de relações e modos de ação e comportamento, ela é uma das linguagens favoritas do povo brasileiro. (...) Ela é capaz de, conforme o contexto, diluir, cristalizar, celebrar, ironizar, ritualizar ou sacralizar a experiência social particular dos grupos que a realizam.

Ressalta ainda Amaral (1998) que a festa medeia estruturas econômicas, simbólicas e míticas ajudando nos conflitos e nas contradições da vida social, ou seja, entre a utopia e a ação transformadora. Que na vontade de realizá-la os grupos tendem a organizar-se e, com isso, a atingir finalidades específicas, além de que,

[...] toda festa, mesmo quando puramente laica em suas origens, tem certas características de cerimônia religiosa, pois, em todos os casos ela tem por efeito aproximar os indivíduos, colocar em movimento as massas e suscitar assim um estado de efervescência, às vezes mesmo de delírio, que não é desprovido de parentesco com 0 estado religioso (DURKHEIM, 1968, p. 547).

Desse modo, nas festas de cunho sagrado, os indivíduos que formam a coletividade são os que vivenciam a mesma religião e "sentem-se ligados uns aos outros pelo simples fato de terem uma fé comum" (DURKHEIM, 1968, p. 28). Independente do grupo, o homem religioso sente necessidade de ocupar "seu" espaço sagrado, por meio do qual se orienta no universo. Essa necessidade não 


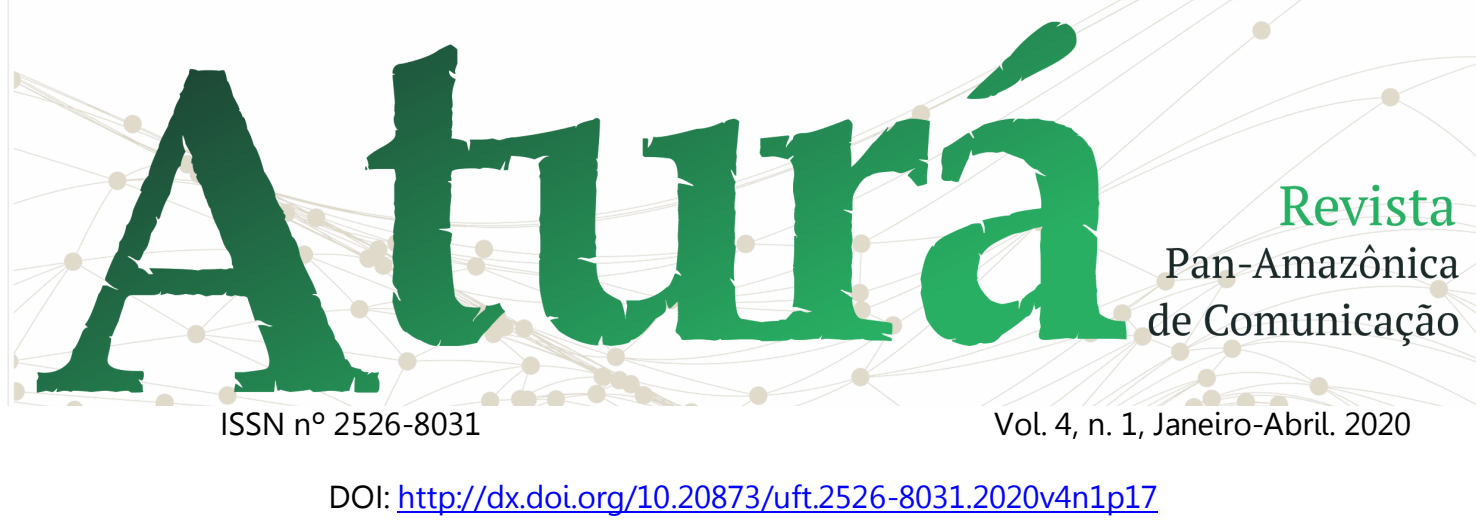

é arbitrária e se apresenta tal qual em nossa existência diária, na qual consolidamos o nosso mundo particular pelos espaços mais significativos vivenciados em nossa trajetória de vida, como, "a paisagem natal ou os sítios dos primeiros amores, ou certos lugares na primeira cidade estrangeira visitada na juventude" (ELIADE, 1992, p. 18).

Para o indivíduo não-religioso, esses lugares também são especiais, pois guardam qualidades únicas como lugares sagrados do seu universo privado, e isso ocorre no quotidiano entre amigos em que, por mais simples que seja o objetivo, há sempre um motivo para festejar, configurando-se atualmente como um novo cenário social.

Novos paradigmas têm surgido com ênfase na cultura, na política e na economia imbricados à ideia de pósmodernidade e com eles as discussões sobre a complexidade de expressões artístico-estéticas, por exemplo, imersas em expressões da cultura popular. Essas, por sua vez, adaptam-se a um modelo que possibilita manter as características básicas de produção e consumo em seu próprio meio social.

Todavia, não se concebe a ideia de pós-modernidade sem relacioná-la a de modernidade. Desse modo, afirma Coelho (1997), que um traço distintivo entre elas seria o modo como os indivíduos se relacionam com a ideia de tempo, pois na pós-modernidade $\mathrm{o}$ individualismo cede lugar a pessoa plural; a crença no presente e o racionalismo sucumbem em detrimento da valorização do presente e do sentimento; outra característica da modernidade residia em relação às diferenças: a redução de tudo em um.

Hoje, o "espírito coletivo" da pósmodernidade inclui a diversidade, em todos os aspectos: cultural, religioso etc. e, a partir dessa nova configuração, percebese, de modo holístico, que a imagem projetada de um mosaico preserva a harmonia entre as partes, apesar de suas diferenças (MAFFESOLI, 2005).

Outro olhar na pós-modernidade enfatiza as vibrações espirituais e artísticas 


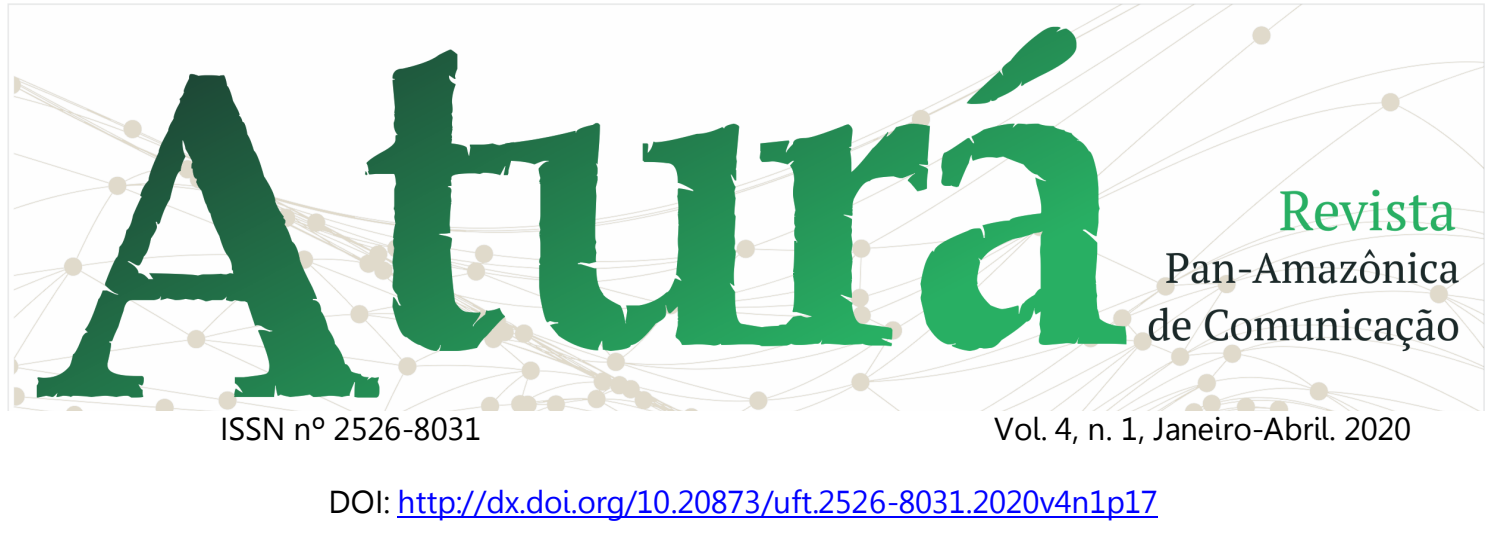

que são acentuadas dando lugar à sintonia e a empatia com os outros humanos. Trata-se de uma construção social, de base sólida, da ética da estética (das emoções e do compartilhamento dos afetos), perceptível nas diversas manifestações artísticas, esportivas, entre outras, na interdependência do coletivo na ordem pós-moderna. Propõe Sodré (2017) diante da sociedade que começa a se dissipar que o outro não é o espelho da gente.

$\mathrm{Na}$ contramão da filosofia cartesiana, Sodré (2017) apresenta modos ou formas diferentes de ver e pensar 0 mundo, sobretudo, o outro, ao que ele denomina de filosofia nagô. Nesse modo, faz-se o passeio pela crença do outro sem a dimensão do preconceito, visto que a verdade é consensual, é relativa. Ao pensar os mitos das festas amazônicas, com base em Sodré (2017) compreende-se que os mitos são constitutivos, o mito nos cria, nos institui e sustenta a cultura. Maffesoli (2005) vê esse novo momento como "crise", que não é apenas econômica, mas social - uma atmosfera mental diferente, específica dessa época. Segundo o autor, O que salta de tudo isso é uma inegável mudança no modo de viver as relações sociais. Todos os pontos fortes, a partir dos quais a modernidade as concebera, indivíduo, identidade, organizações contratuais, atitude projetiva, dão lugar a uma outra realidade muito mais confusa, sensível, emocional, de contornos pouco definidos e do ambiente evanescente. (MAFFESOLI, 2005, p. 348).

Nesse ambiente pós-moderno, a Amazônia se projeta, quer seja pela condição geográfica ou espacial, pela biodiversidade ou pelas interações sociais nas quais muito de sua realidade é apresentada, especialmente pela mídia. Como representação simbólica, a Amazônia reflete um ecossistema rico e diverso, em contraponto a uma pobreza social e conflitos sobre a terra que invadem $\mathrm{o}$ contemporâneo com a dominação forte da colonialidade. De modo positivo, a projeção motivou e viabilizou o acesso aos bens de consumo da medicina caseira, dos artefatos indígenas, dentre outros, para eclodir como produtos da "marca". 


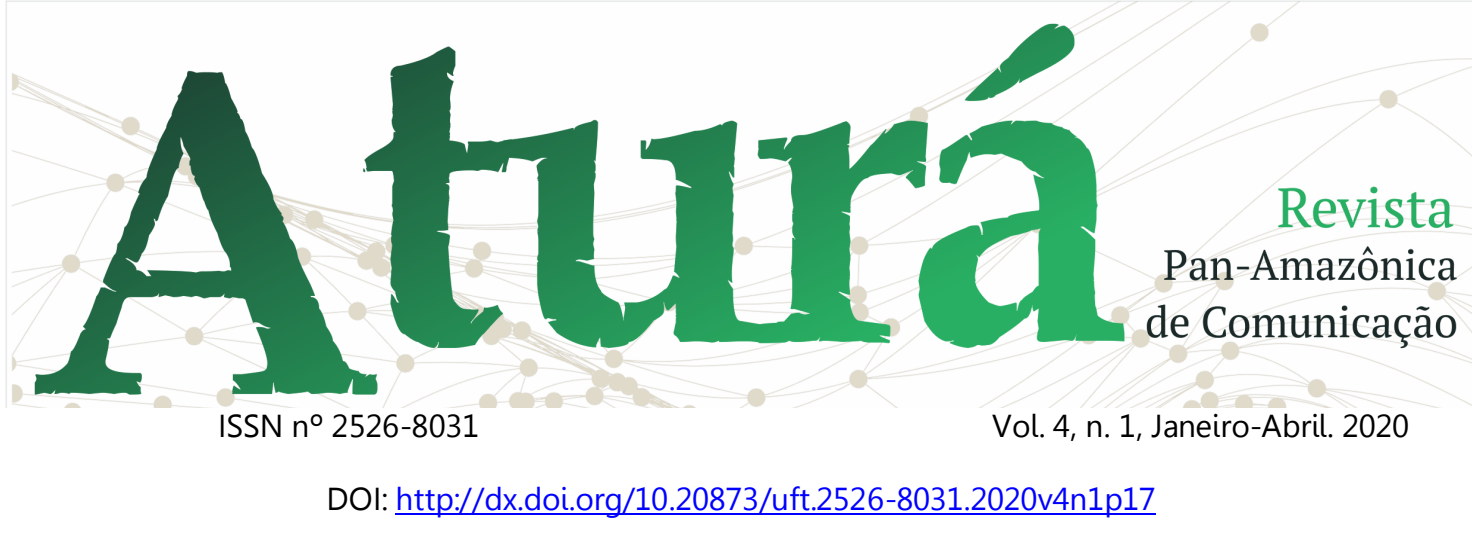

Nesse processo, passou à produção de inúmeros artigos, tanto do artesanato, quanto da indústria da beleza e farmacêutica, além do turismo em todas as suas vertentes, agregando valor econômico e mercadológico a esses produtos. Dessa relação de comercialização estabelecida por meio do trabalho da cultura, os rituais de consumo são organizados e instituídos "por um intenso processo de sedução e 'persuasão clandestina' que visa agora a um consumo dirigido como parte do discurso da publicidade" (AMARAL FILHO, 2016 p. 237). Para Amaral Filho (2008, p. 16), a transformação da natureza em produto produziu uma marca global "institucionalizada por parâmetros socioeconômicos e culturais publicizados em escala mundial pelo campo da comunicação". Os rituais de consumo organizam-se na ordem da economia de mercado, pela oferta de um complexo de produtos e serviços que se diversificam a partir de possibilidade existentes no processo generalizado da produção. Os espetáculos culturais entram na oferta por que atraem o grande público e representam a vida e a tradição local e potencializam a geração de trabalho e renda, reajustando, desse modo, relações econômicas e sociais internas de comunidades e do mercado.

Do ponto de vista prático, nos espetáculos
culturais, esse processo é incorporado pela
narrativa midiática com base no
agendamento e na publicização da cultura
popular no formato usado pelo jornalismo
e pela publicidade. (...) tendo como base a
natureza simbólica da cultura e este rico
imaginário que por ela é oferecido
(AMARAL; ALVES, 2018, p. 38)

Para o objetivo proposto nesse artigo, buscou-se fazer a leitura das músicas dos Bois, de Parintins e das Tribos, de Juruti - no ano de 2019 -, a fim de identificar traços de colonialidade nessas composições. Vale lembrar que mesmo na contemporaneidade, as festas indígenas ainda "guardam lembranças de um passado que se perdeu na voragem da conquista" (SOUZA, 2001, p. 26), e, assim, celebrar "festivamente as origens não é 


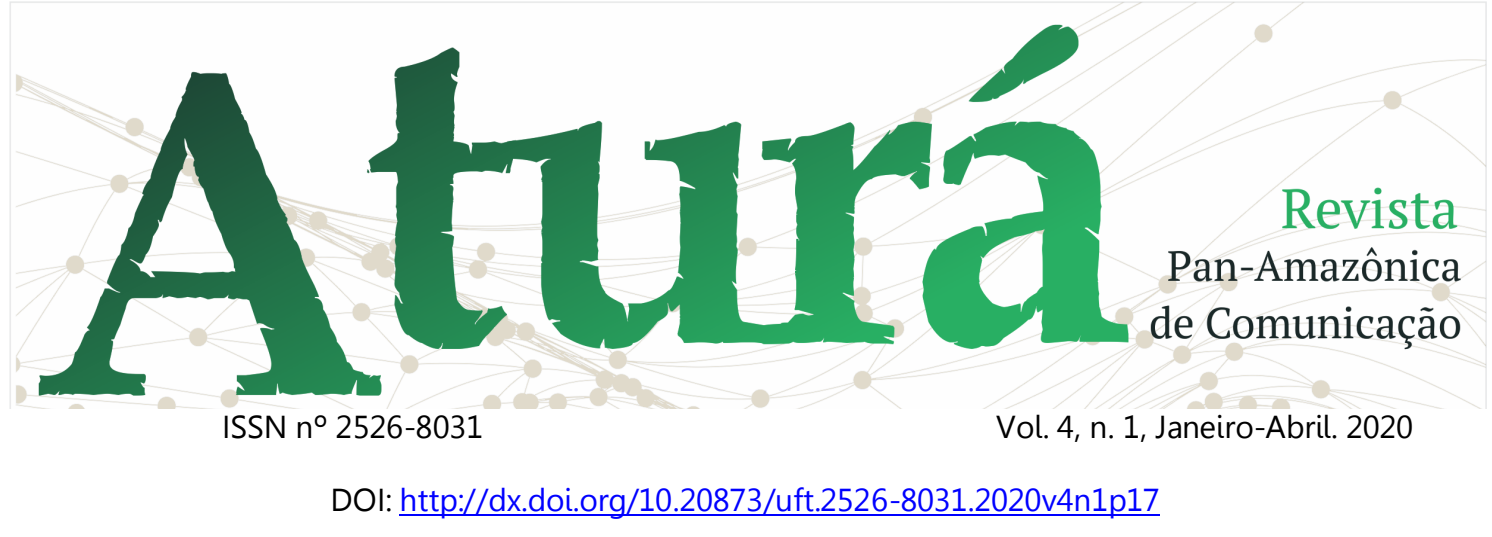

pois um simples retorno lembrador ao passado enquanto passado, mas a memória participativa de um passado matricial que envolve, incorpora e identifica o presente de quem celebra" (TEIXEIRA, 2010, p. 31).

A festa das tribos (2019) ou o $25^{\circ}$ Festribal, cujo tema é "Resistência Indígena no Coração do Brasil" busca valorizar a cultura, o legado e trata da resistência indígena configurada em todo o processo histórico de violência e opressão na região desde a chegada do colonizador. As duas tribos de Juruti, no estado do Pará, autodefinem-se como:

Tribo Munduruku - a composição homenageia as Amazonas, mulheres guerreiras denominadas pelo espanhol Francisco Orellana, e que Frei Gaspar de Carvajal as chamou de índias Icamiabas. Essas lendárias mulheres habitavam a região do rio Nhamundá, entre os estados do Amazonas e Pará. Sob as cores amarelo e vermelho e o título 'Brasil, não silenciarás o nosso canto ancestral', a tribo
Munduruku faz lembrar que os povos indígenas continuam sendo explorados desde a chegada do estrangeiro, e canta do tribódromo em forma de vocativo que diz:

Sou munduruku, eu sou dono dessa terra. Canta galera vermelha e amarela. Com muito amor. Eu sou munduruku. Eu sou torcedor! (SER MUNDURUKU, 2019).

Tribo Muirapinima - Em cores azul e vermelho, a tribo trouxe o canto "Legado Indígena" e ressaltou a importância dos povos indígenas impresso nos costumes e tradições, lendas, indumentárias e o modo de vida, destacando o amor pela mãeterra e a necessidade de proteção e preservação do meio ambiente. $O$ canto é denominado "Espírito" e expressa emoção:

Oh, oh, oh, oh. Deixa fluir a emoção azulvermelha. e vem cantar com a nação Muirá. [...] Muirapinima é amor. É garra e calor. Vem pro delírio da galera azul e vermelha. que comanda a alegria dessa festa. quando toca o regional [...] Muirá é magia, a luz que nos guia e faz cantar minha nação [...]. (CANTOS INDÍGENAS, 2019) ${ }^{11}$.

Em Parintins, no estado do Amazonas, a disputa ocorre entre a nação

\footnotetext{
${ }^{11}$ Compositor Junior Coelho.
} 


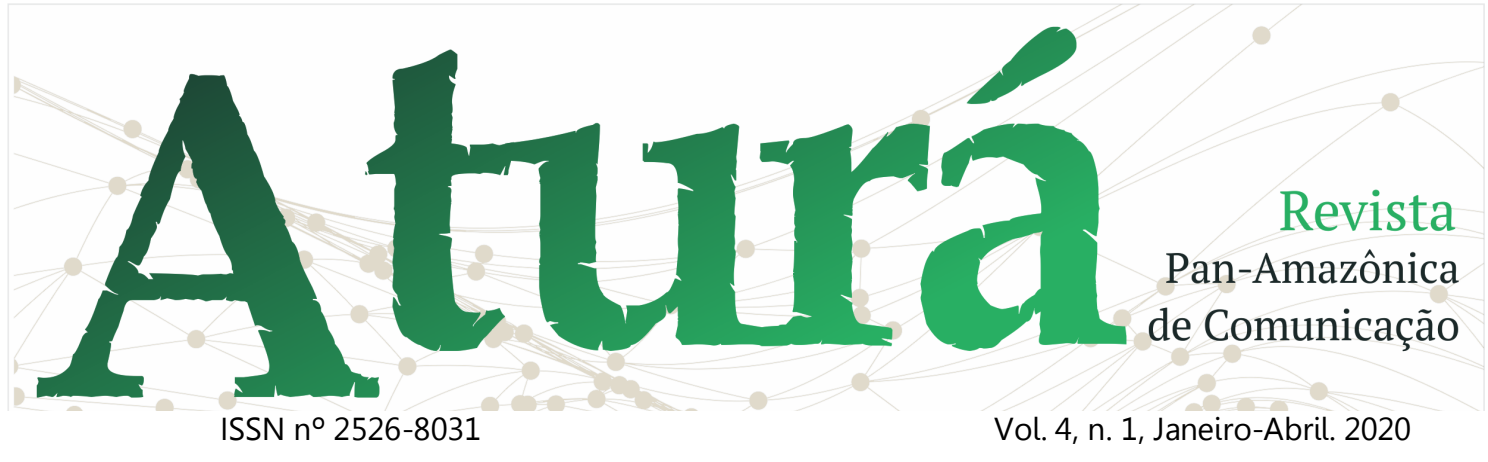

DOI: http://dx.doi.org/10.20873/uft.2526-8031.2020v4n1p17

vermelha e a azul e branco. São elas, respectivamente:

Boi Garantido - O canto "Sonhos de Liberdade" é um chamamento de (re)conhecimento do povo amazônico relacionado à terra. Por meio de "O Boi da Liberdade do Povo", enfatizou o folclore e como resistência "pelo fim da violência, do machismo e da homofobia" e liberdade.

\begin{abstract}
Vem, vem, Brasil [...] nossa arte é guerreira. É pulsante altaneir. É o espelho do povo. É cultura popular [...] $\mathrm{Na}$ estrada do tempo, sonhar, avançar, conquistar. É a cara de Parintins. É, é, é identidade que vem da raiz. [...] a toada é guerreira vermelha, revolucionária do meu boi-bumbá. Liberdade, cultura e arte, bandeiras de sonho a tremular. $O$ jeito, a fé, o gingado, o calor, mulheres e homens de ferro e flor, um povo festeiro, orgulhosos e bravio, e nessa mistura meu nome é Brasil. raça (NÓS, 2019) ${ }^{12}$.
\end{abstract}

Boi Caprichoso - "Mátria Brasilis: do Caos à Utopia" foi a narrativa do espetáculo sobre o nascimento do universo. Das lutas travadas e liberta pela utopia, da intolerância às questões sociais em evidência. A mátria une a nação e ilumina.

É o Brasil, mãe negada/Mátria viva explorada/Terra forte açoitada/Pietá
destronada/É O Brasil misturado / Pindorama loteado/Cativeiro mascarado/De contraste camuflado/É o Brasil, cancioneiro que se faz de luzeiro/Bradando a arte do povo/Que ecoa em canto novo/O Brasil que a gente quer reinventar/Nem brincar boi-bumbá/No touro brasileiro/Vem revolucionar/Vem meu povo festeiro/Caprichoso convida o País/Pra brincar no boi de Parintins. raça (UM CANTO, 2019) ${ }^{13}$.

\section{A sociabilidade como suporte das festas amazônicas}

Antes de se tornar produto de exportação, as festas amazônicas possuíam as mesmas características encontradas nos diversos tipos de festas: a aproximação entre os indivíduos; a produção de uma condição de "efervescência coletiva" (desencadeada por músicas, gritos e danças variadas) e, transgressão das normas do grupo, além de mediar diferenças culturais e sociais entre os indivíduos (DURKHEIM, 1968). Portanto, são evidenciadas as sociabilidades entre os indivíduos, as interações sociais como prática no cotidiano da comunidade.

\footnotetext{
${ }^{13}$ Compositores Geovane Bastos e Guto Kawakami.
}

\footnotetext{
${ }^{12}$ Compositores Enéas Dias, Marcos Moura, João Kennedy e Adriano Alencar.
} 


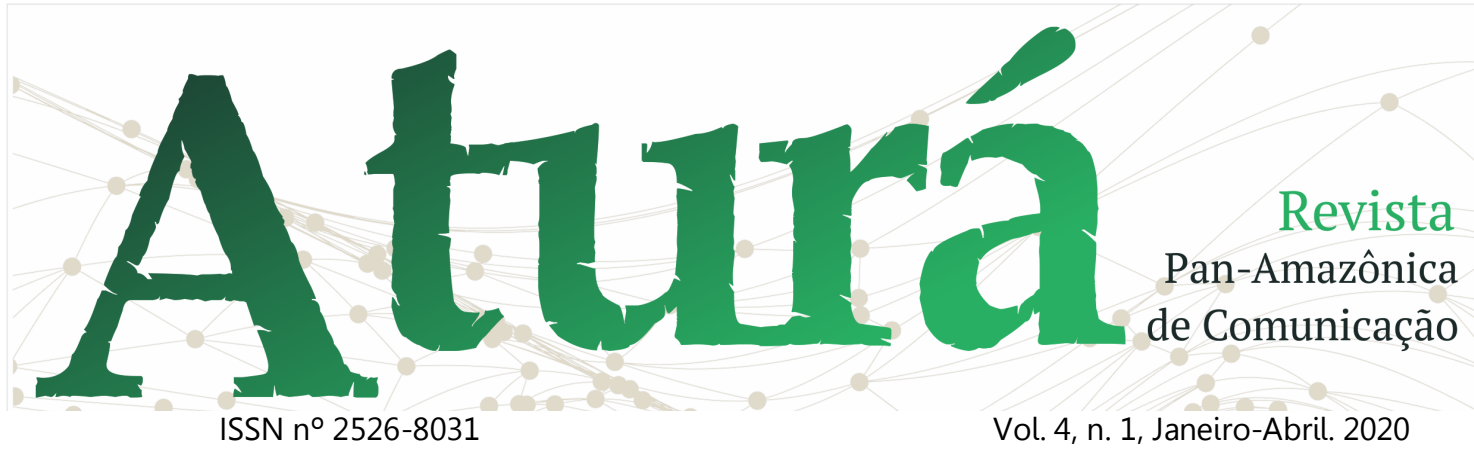

DOI: http://dx.doi.org/10.20873/uft.2526-8031.2020v4n1p17

Nesse contexto, Simmel (1983) concebe como interações sociais as trocas simbólicas que permeiam o ambiente da festa. Como processo social básico é o que constitui a sociedade, ou seja, a pluralidade e as várias formas de interação formam o substrato social. Nesse movimento de consenso e conflito, competição, fazer, desfazer, refazer, um permanente vir-a-ser promove o ambiente da festa por meio dessas múltiplas interações.

Para Simmel (1983, p. 168, grifo nosso):

[...] "sociedade" propriamente dita é o estar com um outro, para um outro, contra um outro que através do veículo dos impulsos ou dos propósitos, forma e desenvolve os conteúdos e os interesses materiais ou individuais. As formas nas quais resulta esse processo ganham vida própria. São liberadas de todos os laços com os conteúdos; existem por si mesmas e pelo fascínio que difundem pela própria liberação destes laços. É isto precisamente o fenômeno que chamamos de sociabilidade.

Essa categoria sociológica é definida por Simmel (1983, p. 169) como "a forma lúdica da sociação" (inúmeras formas de realização de seus interesses), que não se fixa às necessidades e interesses específicos, mas que "se desenvolvem conjuntamente em direção a uma unidade no seio da qual esses interesses se realizam" (SIMMEL, 2006, p. 60). Considera-se, portanto, que as formas de sociação vivenciadas na comunidade ou no grupo de indivíduos são acompanhadas de uma satisfação de estar junto, pelo valor da formação da sociedade enquanto tal.

Na contemporaneidade, a festa como ambiente de sociabilidades engendra novas possibilidades de ampliação evidenciadas pela comunidade e impulsionada pela propaganda e se transforma em "rituais de consumo", da festa da tradição para o espetáculo.

Amaral e Alves (2018, p. 39) afirmam que:

A evolução das manifestações tradicionais para os espetáculos contemporâneos atinge a memória e a linguagem destes eventos pelo enquadramento midiático, portanto, pela publicização, mas antes de tudo por um formato que denominamos de rituais de consumo.

Dessa forma, as festas amazônicas têm alimentado o ciberespaço com o apoio dos meios de comunicação, 


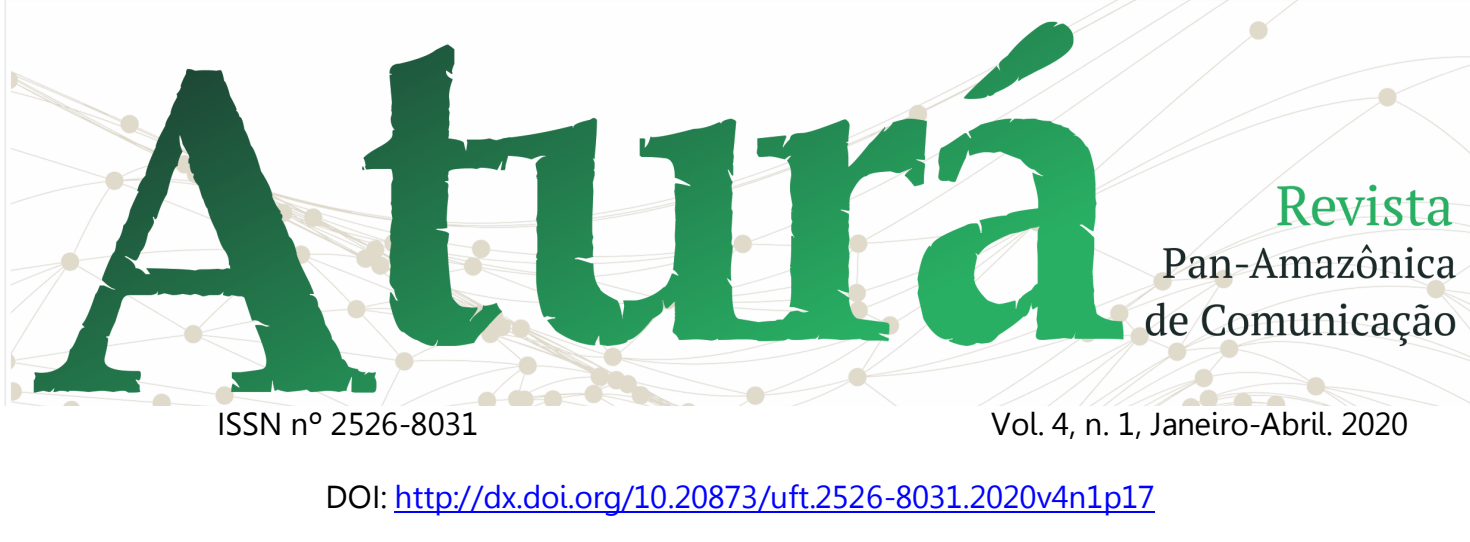

especialmente do jornalismo, que estrategicamente pauta "cenários" transformados em espetáculos. Da origem das festas amazônicas para o espaço destinado a elas houve a ressignificação dos mitos e das lendas, os quais têm que ser reatualizadas a cada novo evento, a fim de se encaixar no formato midiático da pós-modernidade.

\section{Considerações finais}

A ideia do artigo Festas Populares Amazônicas: traços de Colonialidade nas tramas da Pós-Modernidade surgiu a partir da disciplina-base do doutorado em Comunicação, Cultura e Amazônia, na Universidade Federal do Pará, em Belém, em 2019. Nela, termos como colonialidade, sociabilidade, pósmodernidade, dentre outros, subsidiaram os estudos e o olhar lançado para este ensaio sobre as festas populares que ocorrem na região Amazônica, as quais, mesmo anterior à chegada dos europeus, já se faziam presentes, especialmente motivadas

pelas reminiscências culturais de seus antepassados.

Dessa perspectiva, pôde-se observar, sobretudo, por meio dos registros na literatura regional - nos autores referenciados -, que em suas experiências cotidianas e/ou familiares, a questão da colonialidade sempre esteve presente, e que se percebe nos excertos constituídos das dolorosas lembranças desse período colonial. Portanto, propõs-se aqui um olhar descolonial sobre as produções da cultura, como tramas que são, tecidas por esses sujeitos durante o período das festas, na atualidade.

A partir de então, delimitou-se para este ensaio uma análise dos cantosenredos das "tribos" Muirapinima e Munduruku, de Juruti (Pará) e dos Bois Garantido e Caprichoso, de Parintins (Amazonas) no ano de 2019, na identificação de traços de colonialidade nessas composições, o que de fato constatou-se que, cônscio de suas histórias e das imagens (re)produzidas, 


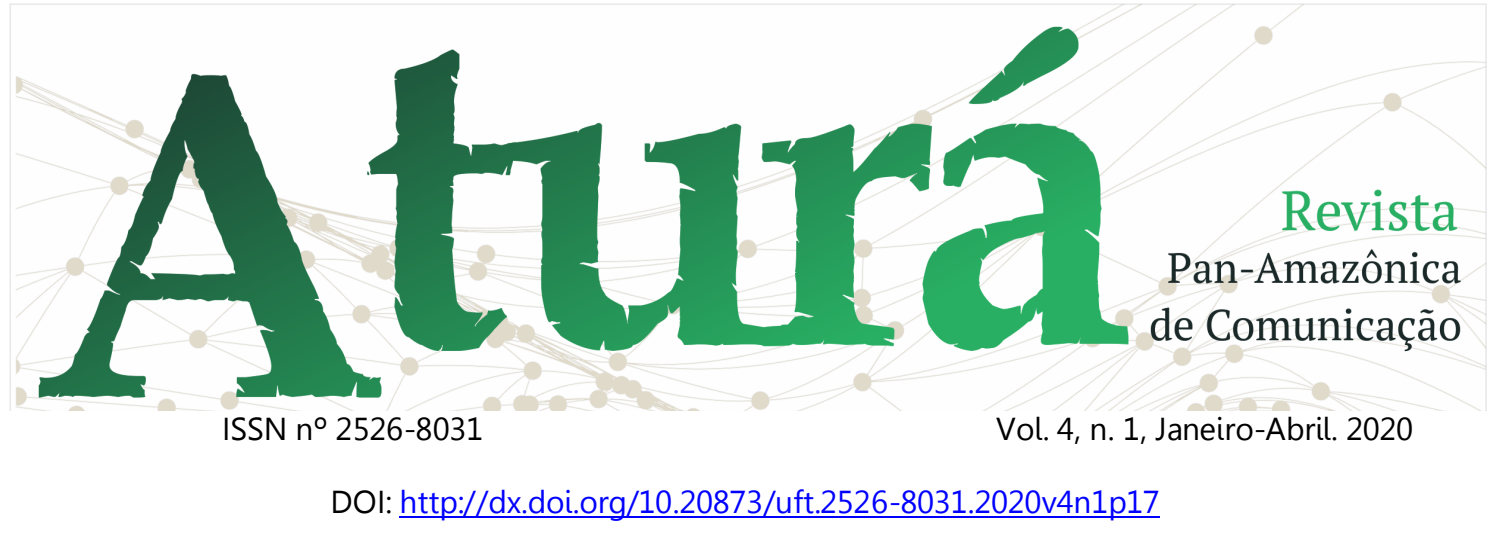

sentimentos de superação resultante da perda, da dor, do sacrifío e de revolta eclodem em forma de arte nas festas populares amazônicas.

Ressalta-se, entretanto, que essa análise recaiu sobre os registros audiovisuais dessas festas voltadas para a composição dos temas-enredos dessas "tribos" (Juruti) e "nação" (como são denominadas as torcidas vermelho e branco e azul e branco dos bois de Parintins). Por isso, recomenda-se que o pesquisador deve conhecê-las, apreendêlas com todos os sentidos, nos cheiros e sabores, nos movimentos da comunidade e da festa, nos ritmos, melodias e nas composições que expressam todos os sentimentos que culminam na festa como manifestação da cultural popular e do lugar.

\section{Referências}

AMARAL FILHO, Otacílio; A Marca Amazônia: uma promessa publicitária para fidelização de consumidores globais. Tese de doutorado do Programa de Pósgraduação em Desenvolvimento
Sustentável do Trópico Úmido, UFPA, Brasil, 2008.

AMARAL FILHO, Otacílio; ALVES, Regina. (Orgs.). Os Espetáculos Culturais na Amazônia: O Cúrio de Nazaré. Curitiba: Editora CRV, 2018.

AMARAL. Rita. As mediações culturais da festa. Mediações, UEL, Londrina, v. 3, n. 1, 1998. (p. 13-22).

ASSIS, Wendell Ficher Teixeira. Do colonialismo à colonialidade: expropriação territorial na periferia do capitalismo. Cad. CRH, Salvador, v. 27, n. 72, 2014. (p. 613-627).

COELHO, Teixeira. Dicionário crítico de política cultural. São Paulo: Iluminuras, 1997.

CANTOS INDÍGENAS de Juruti. 2019. Disponível em $<$ https://apple.co/2OBn7kK>. Acesso em 05 fev. 2019.

COSTA. Antonio M. D. A questão do popular na música da Amazônia paraense da primeira metade do século XX. Revista do Instituto de Estudos Brasileiros, n. 63, 2016. (p. 86-102)

DANIEL, João. Tesouro descoberto no máximo rio Amazonas. Rio de Janeiro: Contraponto, 2004. 


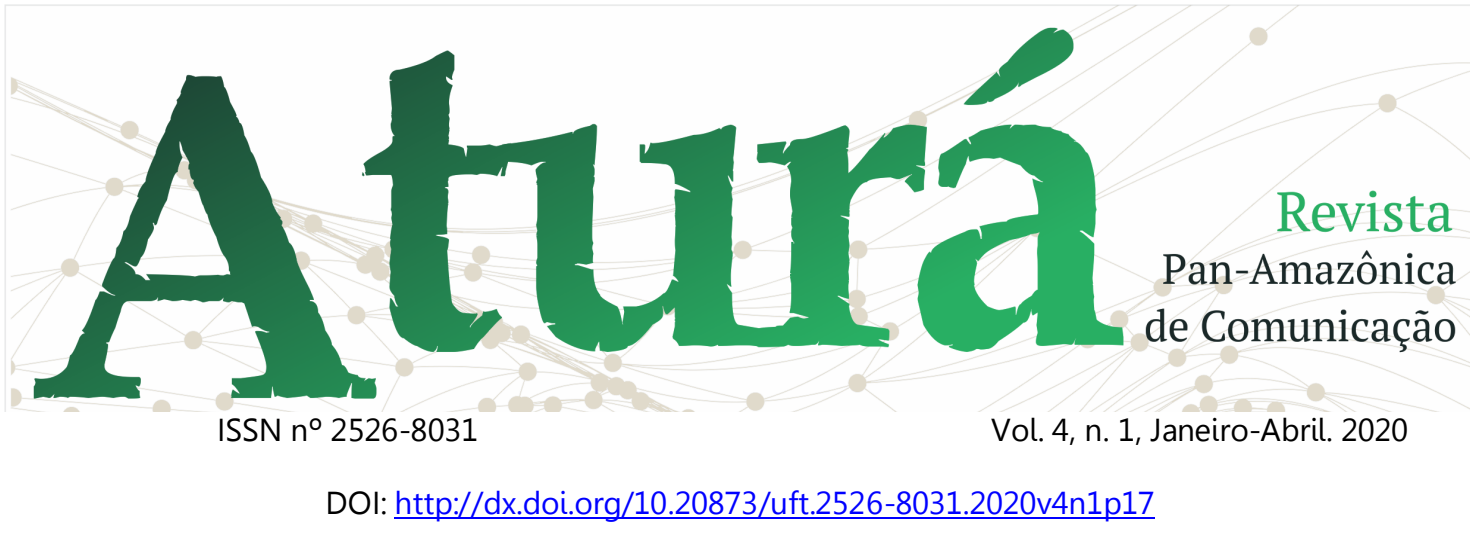

DURKHEIM, Émile. Les formes élémentaires da la vie réligieuse. Paris: PUF, 1968.

ELIADE, Mircea. Mito do eterno retorno. São Paulo: Mercuryo, 1992.

GONDIM, Neide. A invenção da Amazônia. São Paulo: Marco Zero, 1994.

JURANDIR, Dalcídio. Chove nos Campos de Cachoeira. Belém: Cejup, 1991.

LEAL, Luiz Augusto Pinheiro. O Feminino na Formação Intelectual Negra Amazônica. Gênero na Amazônia, Belém, n. 7-12, 2017.

LOUREIRO, João de Jesus Paes. Cantares Amazônicos: poesia. São Paulo: Roswitha Kempf, 1985.

LOUREIRO, João de Jesus Paes. Obras reunidas: poesia I Cultura Amazônica Uma poética do imaginário. São Paulo: Escrituras Editora, 2001.

MAFFESOLI, Michel. No Fundo das Aparências. Petrópolis: Vozes, 1999.

MAFFESOLI, Michel. No Fundo das Aparências. Petrópolis: Vozes, 2005.

MALDONADO-TORRES, Nelson. Sobre la colonialidad del ser: contribuciones al desarrollo de un concepto. In: CASTROGóMEZ, Santiago; GROSFOGUEL, Ramón (Orgs.). El giro decolonial. Reflexiones para una diversidad epistémica más allá del capitalismo global. Bogotá: lesco-PensarSiglo del Hombre Editores, 2007. (p. 127167).

MIGNOLO, Walter. A colonialidade de cabo a rabo: o hemisfério ocidental no horizonte conceitual da modernidade. In: LANDER, Edgardo. (Org.). A colonialidade do saber: eurocentrismo e ciências sociais. Perspectivas latino-americanas. Buenos Aires: Clacso, 2005.

MIGNOLO, Walter. COLONIALIDADE - O lado mais escuro da modernidade.

RBCS, v. 32, n. 94, 2017.

NÓS, o Povo. 2019.

Disponível em: <https://bit.ly/2OyTOiw>. Acesso em 05 fev. 2019.

QUIJANO, Aníbal. Colonialidad del Poder, Cultura y Conocimiento en América Latina. In: Anuário Mariateguiano. Lima: Amatua, 1997.

SALLES, Vicente. Maestro Gama Malcher: A figura humana e artística do compositor paraense. Belém: UFPA/SECULT, 2005b.

SER MUNDURUKU. 2019. Disponível em: $<$ https://bit.ly/2OzCA4D>. Acesso em 05 fev. 2019.

SIMMEL, Georg. Sociologia. In. MORAES FILHO, Evaristo (Org). São Paulo: Ática, 1983. 


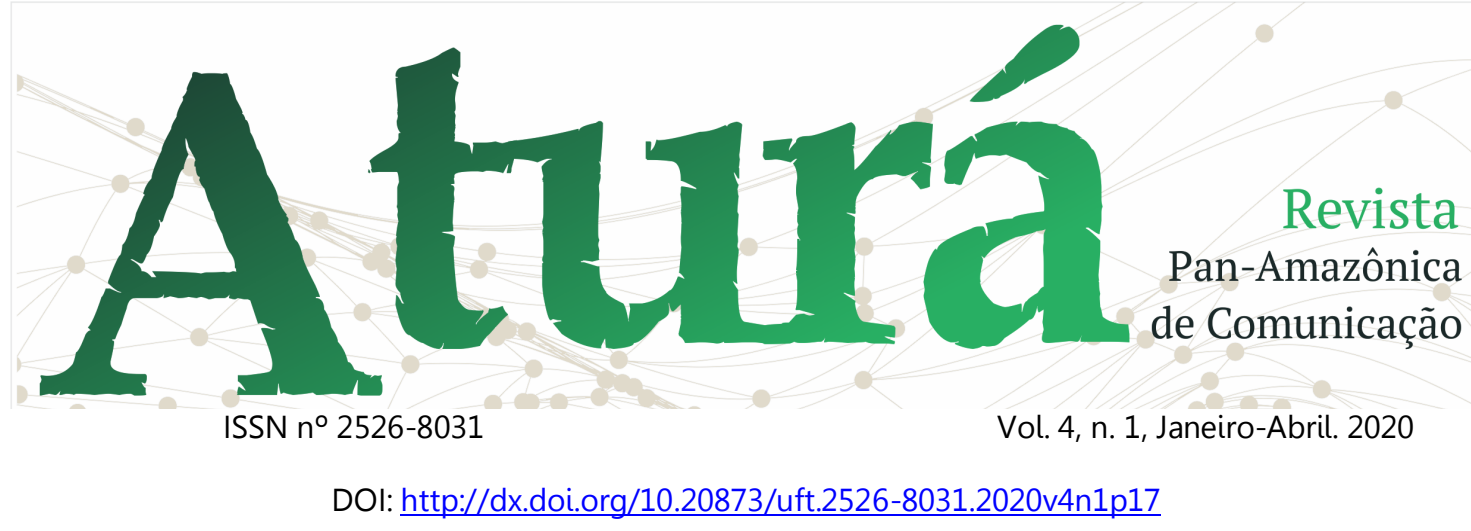

SIMMEL, Georg. Problema da sociologia. In: MORAES FILHO, Evaristo (Org.). Georg Simmel. São Paulo: Ática, 1983.

SIMMEL, Georg. Questões fundamentais da Sociologia: indivíduo e sociedade. Rio de Janeiro: Jorge Zahar, 2006.

SODRÉ. Muniz. Pensar Nagô. Rio de Janeiro: Vozes, 2017.

SOUZA, Márcio. Breve História da Amazônia. São Paulo: Marco Zero, 2001.

TEIXEIRA, Joaquim de Sousa. Festa e Identidade. Comunicação e Cultura. n. 10, 2010. (p. 17-33). Disponível em:

<https://bit.ly/2vYQas5>. Acesso em: 27 jul. 2019.

UM CANTO de Esperança Para Mátria Brasilis. 2019. Disponível em: <https://bit.ly/377bFUa>. Acesso em 05 fev. 2019. 